\title{
THE EFFECT OF INCOME LEVEL, KNOWLEDGE, TAXPAYER AWARENESS AND TAX OFFICER SERVICES ON COMPLIANCE WITH PAYING LAND AND BUILDING TAXES IN PASAR REBO SUBDISTRICT, EAST JAKARTA
}

\begin{tabular}{|c|c|}
\hline $\begin{array}{r}\text { Arnoldus Chri } \\
\qquad{ }_{1} \mathrm{U}\end{array}$ & $\begin{array}{l}\text { Novrianto }{ }^{1} \text { Nurul Aisyah Rachmawati }{ }^{2} \\
\text { sitas Trilogi, Jakarta, Indonesia } 1 \\
\text { sitas Trilogi, Jakarta, Indonesia } 2 \\
\text { rnolduschristo@gmail.com }\end{array}$ \\
\hline INFO ARTIKEL & ABSTRACT \\
\hline $\begin{array}{l}\text { Histori Artikel : } \\
\text { Tgl. Masuk : 22-09-2020 } \\
\text { Tgl. Diterima : 05-02-2021 } \\
\text { Tersedia Online : 31-03-2021 } \\
\text { Keywords: } \\
\text { income level, knowledge, } \\
\text { awareness, service of tax } \\
\text { officers, compliance with } \\
\text { paying land and building taxes. }\end{array}$ & $\begin{array}{l}\text { This study aims to find out the influence of income levels, } \\
\text { knowledge, taxpayer awareness and tax officer services on } \\
\text { the compliance of paying land and building taxes. The } \\
\text { population of this research includes the taxpayers of the } \\
\text { land and buildings located in the city of East Jakarta, } \\
\text { especially in Pasar Rebo District. Questionnaires obtained } \\
\text { after being distributed to respondents amounted to } 110 \text {. } \\
\text { This research uses quantitative approach and uses } \\
\text { structural model analysis (SEM). This research also uses } \\
\text { hypothesis testing in the form of z test. The results shows } \\
\text { that the level of knowledge has no effect on taxpayer } \\
\text { compliance while the level of income, awareness and } \\
\text { service of tax officers has a positive effect on taxpayer } \\
\text { compliance. }\end{array}$ \\
\hline
\end{tabular}

\section{PENDAHULUAN}

Pajak merupakan salah satu sumber pendapatan negara untuk membiayai pengeluaran pemerintah dan pembangunan nasional. Tidak hanya karena kontribusinya yang tinggi bagi pemerintah dan pembangunan, tetapi pajak juga bisa menjadi instrumen fiskal yang efektif dalam mengarahkan perekonomian di Indonesia. Pajak memiliki peran yag sangat penting terhadap pendapatan negara pada masa sekarang. Ini terjadi karena pajak adalah sumber yang pasti dalam memberikan kontribusi kepada negara karena merupakan cerminan dari kegotongroyongan masyarakat dalam pembiayaan negara yang diatur oleh perundang-undangan. (Haswidar, 2016)

Pada dasarnya, masyarakat mengharapkan uang yang diberikan kepada negara dapat digunakan dengan sebaik-baiknya oleh pemerintah untuk kemajuan negara dan kesejahteraan rakyat. Masyarakat ingin melihat jelas apa yang dilakukan oleh pemerintah dengan uang pembayaran pajak dari rakyat. Kenyataannya, yang ada selama ini, sering terjadi para pejabat tinggi pemerintah yang melakukan korupsi uang rakyat untuk kepentingan pribadinya. Menurut (Rantumbanua, 2017) korupsi yang dilakukan oleh pejabat adalah salah satu pemicu kurangnya keyakinan dan kesadaran masyarakat dalam memenuhi kewajiban sebagai warga negara Indonesia.

Salah satu penerimaan dalam pajak, yaitu Pajak Bumi dan Bangunan. Pajak Bumi dan Bangunan adalah iuran yang dikenakan terhadap orang atau badan yang secara nyata mempunyai hak, memiliki, menguasai dan memperoleh 
manfaat dari bumi dan bangunan. Pajak Bumi dan Bangunan yang sebelumnya dikelola oleh pemerintah pusat diserahkan kepada pemerintah daerah, hal ini diatur dalam (UU Nomor 28 Tahun 2009), sebelum Undang-undang ini muncul, Pajak Bumi dan Bangunan merupakan pajak pusat namun dana pemerintah dikembalikan kembali ke daerah kabupaten/kota, sehingga pemerintah daerah tinggal menerima dana bagi hasil dari pemerintah pusat. Dengan terbitnya (UU Nomor 28 Tahun 2009) tentang Pajak Daerah dan Retribusi Daerah, pemerintah daerah kini mempunyai tambahan sumber Pendapatan Asli Daerah yang berasal dari Pajak Daerah salah satunya adalah Pajak Bumi dan Bangunan Perdesaan dan Perkotaan (PBB-P2).

Kepatuhan yang tinggi dari wajib pajak dibutuhkan untuk kelancaran penarikan pajak. Begitu pula dalam pemungutan Pajak Bumi dan Bangunan juga dibutuhkan kepatuhan yang tinggi dari wajib pajak. Kepatuhan wajib pajak adalah salah satu keadaan dimana wajib pajak memenuhi semua kewajiban perpajakan dan melaksanakan hak perpajakannya (Haswidar, 2016). Namun dalam kenyataanya negara sering kesulitan memungut pajak, termasuk Pajak Bumi dan Bangunan.

Menurut (Rahman, 2018) faktor ekonomi merupakan hal yang sangat fundamental dalam hal melaksanakan kewajiban. Masyarakat yang miskin akan menemukan kesulitan untuk membayar pajak, bagi sebagian besar masyarakat, pajak masih dianggap sebagai sebuah beban dan biaya yang harus ditanggung dalam kegiatan ekonominya. Oleh karena itu, masyarakat akan lebih cenderung untuk memenuhi kebutuhan pokoknya terlebih dahulu.

Semakin meningkatnya pengetahuan perpajakan maka akan meningkat pula kepatuhan wajib pajak dalam membayar pajak karena dengan pengetahuan perpajakan menjadikan wajib pajak lebih mengerti dan memahami akan pentingnya membayar pajak. Dengan tingkat pengetahuan yang cukup baik, maka akan dapat diwujudkan wajib pajak yang sadar pajak dan mau memenuhi kewajiban perpajakannya.

Kesadaran perpajakan berpengaruh signifikan terhadap kepatuhan wajib pajak. menurut (Utomo, 2011) dalam penelitiannya, kesadaran wajib pajak berpengaruh signifikan terhadap kepatuhan wajib pajak. Secara garis besar kesadaran perpajakan dalam arti prosedur meliputi tahap-tahap antara lain, pendaftaran wajib pajak, penetapan pajak, dan penagihan pajak. Tahap-tahap yang tidak sesuai prosedur merupakan sumber kecurangan. Dengan adanya diwajibkan pendaftaran wajib pajak, penetapan pajak yang tepat untuk Pajak Bumi dan Bangunan, dan penagihan pajak yang baik maka akan memberikan dampak terhadap kepatuhan wajib Pajak Bumi dan Bangunan dalam membayar pajak.

Kendala utama yang menyebabkan kegagalan tercapainya target penerimaan pajak adalah kepatuhan wajib pajak untuk memiliki kemauan melaksanakan kewajibannya dalam membayar pajak. Kurangnya kemauan wajib pajak dalam membayarkan kewajiban pajaknya dikarenakan oleh berbagai faktor, seperti tingkat pendapatan dari wajib pajak, kurangnya pengetahuan dari wajib pajak, kurangnya kesadaran wajib pajak dalam membayarkan kewajibannya (Koentarto, 2011).

Upaya peningkatan kualitas fiskus yang dilakukan pemerintah untuk meningkatkan penerimaan pajak terbukti dengan munculnya peraturan baru. Menurut (Pasal 11 huruf i Peraturan Menteri Keuangan Republik Indonesia Nomor 184/PMK.03/2015), berbunyi "Fiskus memiliki kewajiban untuk melakukan pembinaan kepada Wajib Pajak dalam memenuhi kewajiban perpajakannya sesuai dengan ketentuan peraturan perundang-undangan perpajakan dengan menyampaikan saran secara tertulis." Berdasarkan peraturan tersebut dapat diartikan bahwa fiskus diwajibkan terjun langsung ke masyarakat 
untuk memberikan pengarahan dan pendampingan secara langsung kepada masyarakat sehingga diharapkan masyarakat memiliki kemauan untuk membayarkan kewajiban pajaknya (Widowati, 2014). Menurut (Ariani \& Biettant, 2019) dalam penelitiannya menyatakan bahwa pelayan fiskus berpengaruh signifikan terhadap kepatuhan wajib pajak. Oleh karenanya diharapkan petugas fiskus dapat meningkatkan pelayanannya. Hal ini semestinya juga dilakukan oleh fiskus yang ada di Kecamatan Pasar Rebo dengan tujuan agar penerimaan pajak termasuk dalam pajak bumi dan bangunan dapat tercapai bahkan melampaui target yang telah ditentukan sebelumnya.

Pemungutan pajak bukan pekerjaan yang mudah, disamping peran aktif dari petugas perpajakan, juga dituntut kesadaran dari wajib pajak itu sendiri. Oleh karena itu, diharapkan setiap masyarakat memiliki kesadaran yang tinggi untuk memenuhi kewajiban membayar pajak. Selanjutnya, kepatuhan seseorang dalam memenuhi kewajiban sebenarnya dipengaruhi oleh banyak faktor antara lain pendidikan, pendapatan, dan kualitas pelayanan fiskus. Penelitian ini bertujuan untuk mengetahui pengaruh tingkat pendapatan, pengetahuan, kesadaran dan pelayanan petugas pajak terhadap kepatuhan membayar pajak bumi dan bangunan di Pasar Rebo Kota Jakarta Timur, sehingga bisa memberikan manfaat bagi wajib pajak itu sendiri dan juga manfaat bagi petugas pajak. Penelitian ini berkontribusi secara teoretis dan praktis. Secara teoritis, dapat memberikan tambahan terhadap literatur ataupun referensi lebih lanjut dalam hal tingkat pendapatan, pengetahuan, kesadaran wajib pajak dan pelayanan petugas pajak dalam konteks kepatuhan wajib pajak bumi dan bangunan. Sebagai bentuk kontribusi praktis, temuan penelitian ini diharapkan dapat menjadi referensi sebagai bahan penilaian atau sebagai masukan dan pertimbangan yang terkait dalam menilai dan mengupayakan kepatuhan wajib pajak khususnya wajib pajak bumi dan bangunan agar dapat memenuhi kewajibannya sebagai wajib pajak.

\section{KERANGKA TEORITIS DAN PENGEMBANGAN HIPOTESIS}

\section{Pajak Daerah}

Pajak merupakan salah satu sumber penerimaan yang utama bagi pemerintah setiap negara. Pajak adalah masalah negara dan setiap orang hidup dalam suatu negara pasti berurusan dengan pajak, oleh sebab itu persoalan pajak juga menjadi persoalan seluruh rakyat dalam suatu negara. Maka setiap orang sebagai anggota masyarakat suatu negara harus mengetahui segala permasalahan yang berkaitan dengan pajak, baik mengenai azasnya jenis pajak yang berlaku, tata cara pembayaran pajak serta hak dan kewajiban sebagai wajib pajak. Pada umumnya bagi masyarakat pajak merupakan pengertian hal tidak menyenangkan, akan tetapi tidak dapat dielakkan, hal ini disebabkan tidak nampak prestasi langsung yang diberikan oleh pemerintah kepada wajib pajak.

Menurut (Soemitro, 2016:6) menjelaskan pengertian pajak adalah iuran rakyat kepada negara berdasarkan undang-undang yang dapat dipaksakan dengan tidak mendapat imbalan yang secara langsung dapat ditujukan, yang digunakan sebagai alat pendorong, penghambat atau pencegah untuk mencapai tujuan yang ada dalam bidang keuangan negara.

Menurut (Pasal 1 UU No. 28 Tahun 2009). "pajak daerah adalah iuran wajib pajak kepada daerah untuk membiayai pembangunan daerah". Pajak daerah ditetapkan dengan undang-undang yang pelaksanaannya untuk di daerah diatur lebih lanjut dengan peraturan daerah. Pemerintah daerah dilarang melakukan pumungutan selain pajak yang telah ditetapkan undang-undang. Pengertian tersebut dapat disimpulkan bahwa, Pajak Daerah adalah jenis pajak yang dipungut 
pemerintah daerah yang dalam pelaksanaannya sehari-hari dilakukan Dinas Pendapatan Daerah (Dispenda), yang digunakan untuk membiayai penyelenggaraan pemerintah daerah dan pembangunan daerah.

Untuk membiaya dan memajukan suatu daerah maka ditempuh suatu kebijaksanaan yang mewajibkan setiap orang untuk membayar pajak sesuai dengan kewajibannya. Pajak daerah pada hakikatnya tidak ada perbedaan pengertian pokok antara pajak negara dengan pajak daerah mengenai prinsipprinsip umum hukumnya. Perbedaan yang hanya pada aparat pemungut dan penggunaan pajak.

Pajak daerah sebagai salah satu sumber PAD diharapkan menjadi salah sumber pembiayaan penyelenggaraan pemerintah dan pembangunan daerah untuk meningkatkan dan memeratakan kesejahteraan masyarakat. Dengan demikian daerah mampu melaksanakan otonomi, yaitu mampu mengatur dan mengurus rumah tangganya sendiri.

\section{Pajak Bumi dan Bangunan}

Pajak Bumi dan Bangunan merupakan pajak yang dikenakan terhadap hampir seluruh lapisan masyarakat dan merupakan salah satu sumber utama penerimaan daerah. Dalam APBD, penerimaan Pajak Bumi dan Bangunan tersebut dimasukkan dalam kelompok penerimaan daerah dari bagi hasil pajak. Pajak Bumi dan Bangunan adalah pajak yang dikenakan terhadap bumi dan bangunan. Sebagaimana yang tercantum dalam Pasal 1 UU No.12 Tahun 1994 Tentang Pajak Bumi dan Bangunan adalah "Bumi adalah merupakan dan tubuh bumi yang ada dibawahnya sedangkan bangunan adalah konstruksi teknik yang ditanam atau diletakkan secara tetap pada tanah atau bangunan".

Peraturan Daerah Provinsi Daerah Khusus lbukota Jakarta nomor 16 tahun 2011 pasal 4 menjelaskan mengenai subjek pajak bumi dan bangunan. Subjek pajak adalah orang pribadi atau badan yang secara nyata mempunyai suatu hak atas bumi dan/atau memperoleh manfaat atas bumi, dan/atau memiliki, menguasai, dan/atau memperoleh manfaat atas bangunan. Subjek pajak dan wajib pajak tidak diketahui keberadaannya maka Gubernur dapat memberikan tanda khusus atas tanah dan/atau bangunan yang dimaksud.

\section{Kepatuhan Wajib Pajak}

Kepatuhan adalah motivasi seseorang kelompok atau organisasi untuk berbuat atau tidak berbuat sesuatu sesuai dengan aturan yang telah ditetapkan. Perilaku kepatuhan seseorang merupakan interaksi antara perilaku individu, kelompok dan organisasi (Purbo, 2012).

Kepatuhan wajib pajak yaitu kepatuhan perpajakan yang didefinisikan sebagai suatu keadaan dimana wajib pajak memenuhi semua kewajiban perpajakan dan melaksanakan hak perpajakannya. Adanya kepatuhan secara tidak langsung penerimaan pajak akan berjalan dengan lancar karena kepatuhan wajib pajak telah menunjukkan bahwa wajib pajak telah melaksanakan kewajiban perpajakan dengan baik.

Sedangkan menurut Keputusan Menteri Keuangan No. 544/kmk.04/2000 kepatuhan perpajakan adalah tindakan wajib pajak dalam pemenuhan kewajiban perpajakan sesuai dengan ketentuan peraturan perundang-undangan dan peraturan pelaksanaan perpajakan yang berlaku dalam suatu negara.

\section{Tingkat Pendapatan Wajib Pajak}

Dalam pemungutan pajak perlu memperhatikan kemampuan wajib pajak dalam membayar pajak, kemampuan membayar itu sendiri dipengaruhi oleh tingkat pendapatan, oleh karena itu pajak harus dipungut pada saat yang tepat, yaitu pada saat wajib pajak mempunyai uang. Pendapatan adalah tanggung 
jumlah uang atau nilai yang selama tahun takwim diperoleh seseorang dari.

Faktor ekonomi merupakan hal yang sangat fundamental dalam hal ini melaksanakan kewajiban. Masyarakat yang miskin akan menemukan kesulitan untuk membayar pajak. Kebanyakan mereka akan memenuhi kebutuhan hidup terlebih dahulu sebelum membayar pajak. Karenanya, tingkat pendapatan seseorang dapat mempengaruhi bagaimana seseorang tersebut memiliki kesadaran dan kepatuhan akan ketentuan hukum dan kewajibannya.

Kondisi keuangan adalah kemampuan keuangan individu dalam memenuhi segala kebutuhannya. Apabila individu tersebut dapat memenuhi semua kebutuhan tersebut, baik itu kebutuhan primer, sekunder, maupun tersier berdasarkan pendapatan yang dimiliki tanpa bantuan dari pihak luar berupa pinjaman, dapat dikatakan bahwa kondisi keuangan individu tersebut sangat baik. Akan tetapi, jika individu tersebut seringkali melakukan pinjaman dari pihak luar yang biasa diperoleh dari keluarga, teman, maupun bank, dapat dikatakan bahwa kondisi keuangan individu tersebut sangat buruk (Agustiantono, 2012:27).

\section{Tingkat Pengetahuan Wajib Pajak}

Pengetahuan adalah hasil tahu manusia terhadap sesuatu, atau segala perbuatan manusia untuk memahami suatu objek tertentu yang dapat berwujud barang-barang baik lewat indera maupun lewat akal, dapat pula objek yang dipahami oleh manusia berbentuk ideal, atau yang bersangkutan dengan masalah kejiwaan. Pajak adalah iuran rakyat kepada kas negara berdasarkan UndangUndang (yang dapat dipaksakan) dengan tidak mendapat jasa timbal balik yang langsung dapat ditujukkan dan yang digunakan untuk membayar pengeluaran umum (Mardiasmo, 2009:1). Jadi kesimpulan pengetahuan perpajakan adalah kemampuan atau seorang wajib pajak dalam mengetahui peraturan perpajakan baik itu soal tarif pajak berdasarkan Undang-Undang yang akan mereka bayar maupun manfaat pajak yang akan berguna bagi kehidupan mereka.

Dengan adanya pengetahuan perpajakan tersebut akan membantu kepatuhan wajib pajak dalam membayar pajak, sehingga tingkat kepatuhan akan meningkat. Pada umumnya seseorang yang memiliki pendidikan, akan sadar dan patuh terhadap hak dan kewajibannya, tanpa harus dipaksakan dan diancam oleh beberapa sanksi dan hukuman. Wajib pajak yang berpengetahuan tentang pajak, secara sadar diri akan patuh membayar pajak. Mereka telah mengetahui bagaimana alur penerimaan pajak tersebut akan berjalan, hingga akhirnya manfaat membayar pajak tersebut dapat dirasakannya.

\section{Kesadaran Wajib Pajak}

Kesadaran berasal dari kata sadar yang berarti yakin, merasa, tahu, dan mengerti. Sedangkan kesadaran yang dimaksud di sini adalah wajib pajak selalu berusaha membayar pajak setiap tahun dengan sukarela yakin bahwa pajak berguna bagi pembangunan sehingga dengan kesadaran yang dimiliki oleh wajib pajak maka pembangunan juga akan berjalan lancar (Faizah, 2009:43).

Kesadaran adalah keadaan mengetahui atau mengerti, sedangkan perpajakan adalah perihal pajak. Sehingga kesadaran perpajakan adalah keadaan mengetahui atau mengerti perihal pajak. Penilaian positif wajib pajak terhadap pelaksanaan fungsi negara oleh pemerintah akan menggerakkan masyarakat untuk patuh dalam membayar pajak (Saputra, 2015:8).

\section{Pelayanan Petugas Pajak}

Menurut Kamus Besar Bahasa Indonesia, pelayanan berarti usaha untuk melayani kebutuhan orang lain. Sedangkan fiskus berarti aparatur pajak. Menurut (Widowati, 2014), Pelayanan fiskus dapat diartikan cara atau proses petugas pajak dalam melayani atau membantu, mengurus, dan menyiapkan 
segala keperluan yang dibutuhkan wajib pajak. Kewajiban dari fiskus telah diatur dalam peraturan 16 yang dikeluarkan oleh Menteri Keuangan. Menurut (Pasal 11 huruf i Peraturan Menteri Keuangan Republik Indonesia Nomor 184/PMK.03/2015), berbunyi "Fiskus memiliki kewajiban untuk melakukan pembinaan kepada Wajib Pajak dalam memenuhi kewajiban perpajakannya sesuai dengan ketentuan peraturan perundang-undangan perpajakan dengan menyampaikan saran secara tertulis."

\section{Pengaruh Tingkat Pendapatan terhadap Kepatuhan Wajib Pajak Bumi dan Bangunan}

Pendapatan merupakan tambahan kekayaan atau harta yang diperoleh baik dalam maupun dari luar Negara yang dipungut untuk memenuhi kebutuhan hidupnya. Wajib pajak akan lebih memilih menggunakan pendapatannya untuk memenuhi kebutuhan hidupnya, dari pada menggunakan untuk membayar pajak

Selain itu dalam teori ekonomi dikatakan bahwa I atau Income $=\mathrm{C}$ atau Consumption, dimana besarnya penghasilan akan sama dengan besarnya konsumsi. Konsumsi disini termasuk juga pengeluaran untuk membayar pajak karena wajib pajak dianggap melakukan tindakan konsumsi yaitu menghabiskan nilai guna dari suatu barang, dalam hal ini yang dimaksud adalah nilai guna atas tanah dan bangunan.

Karenanya tingkat pendapatan seseorang dapat mempengaruhi bagaimana seseorang tersebut memiliki kesadaran dan kepatuhan akan ketentuan hukum dan kewajibannya. Salah satu penelitian sebelumnya yang terkait dengan penelitian ini yaitu penelitian yang dilakukan oleh (Dewi,dkk. 2017). Penelitian ini tentang identifikasi kemampuan dan kemauan membayar masyarakat berpenghasilan menengah rendah. Hasilnya menyimpulkan variabel pendapatan memiliki pengaruh terhadap kesediaan membayar pajak.
$H_{1}$ : Tingkat pendapatan berpengaruh positif terhadap kepatuhan wajib pajak bumi dan bangunan.

\section{Pengaruh Tingkat Pengetahuan terhadap Kepatuhan Wajib Pajak Bumi dan Bangunan}

Pengetahuan perpajakan adalah kemampuan seorang wajib pajak dalam mengetahui peraturan perpajakan baik itu soal tarif pajak yang akan mereka bayar, maupun manfaat pajak yang akan berguna bagi kehidupan mereka. Semua wajib pajak tanpa tergantung latar belakang pendidikan mereka setuju bahwa pendidikan pajak membantu meningkatkan kepatuhan pajak.

Penelitian ini terkait dengan faktorfaktor yang mempengaruhi kepatuhan wajib pajak. Seseorang yang berpendidikan pajak akan mempunyai pengetahuan tentang perpajakan, baik itu soal tarif pajak yang akan mereka bayar, maupun manfaat pajak yang akan berguna bagi kehidupan mereka. Dengan adanya pengetahuan perpajakan tersebut akan membantu kepatuhan wajib pajak dalam membayar pajak, sehingga tingkat kepatuhan akan meningkat.

Hasil Penelitian (Budhiartama \& Jati, 2016) mengenai pengetahuan perpajakan menyatakan bahwa pengetahuan perpajakan berpengaruh positif terhadap kepatuhan membayar pajak bumi dan bangunan. Semakin tinggi pengetahuan perpajakan maka semakin tinggi pula kepatuhan wajib pajak dalam membayar pajak bumi dan bangunan. Dari pemaparan diatas dapat disimpulkan bahwa pengetahuan diperkirakan akan berpengaruh kepada kepatuhan wajib pajak dalam membayar pajak bumi dan bangunan.

$\mathrm{H}_{2}$ : Tingkat pengetahuan perpajakan berpengaruh positif terhadap kepatuhan wajib pajak bumi dan bangunan. Pengaruh Tingkat Kesadaran Wajib
Pajak terhadap Kepatuhan Wajib Pajak
Bumi dan Bangunan 
Kesadaran perpajakan adalah kerelaan memenuhi kewajibannya, termasuk rela memberikan kontribusi dana untuk pelaksanaan fungsi pemerintah dengan cara membayar kewajiban pajaknya. Kesadaran perpajakan berkonsekuensi logis untuk wajib pajak, yaitu kerelaan wajib pajak memberikan kontribusi dana untuk pelaksanaan fungsi perpajakan, dengan cara membayar kewajiban pajaknya secara tepat waktu dan tepat jumlah (Utomo, 2011).

Wajib pajak yang menyadari akan pentingnya pajak bagi negara maka akan membayar kewajiban pajaknya secara tepat waktu dan tepat jumlah. Kesadaran perpajakan wajib pajak berpengaruh terhadap keberhasilan penerimaan Pajak Bumi dan Bangunan.

Menurut (Salma, 2018) dalam penelitiannya menyatakan bahwa kesadaran wajib pajak berpengaruh positif terhadap kepatuhan wajib pajak dalam membayar pajak bumi dan bangunan. Semakin tinggi kesadaran dari wajib pajak maka akan semakin tinggi pula kepatuhan wajib pajak dalam membayar pajak bumi dan bangunan. Maka dapat di simpulkan bahwa kesadaran wajib pajak akan berpengaruh terhadap kepatuhan wajib pajak dalam membayar pajak bumi dan bangunan.

$\mathrm{H}_{3}$ : Tingkat kesadaran berpengaruh positif terhadap kepatuhan wajib pajak bumi dan bangunan.

\section{Pengaruh Pelayanan Fiskus terhadap Kepatuhan Wajib Pajak Bumi dan Bangunan}

Pelayanan merupakan cara yang dilakukan untuk memenuhi kebutuhan orang lain. Sedangkan menurut (Widowati, 2014), Pelayanan fiskus dapat diartikan cara atau proses petugas pajak dalam melayani atau membantu, mengurus, dan menyiapkan segala keperluan yang dibutuhkan wajib pajak. Kewajiban fiskus salah satunya ialah melayani segala hal yang dibutuhkan oleh wajib pajak dengan tujuan agar wajib pajak bersedia untuk melaksanakan kewajibannya dalam hal melakukan pembayaran pajak. Kewajiban fiskus terhadap wajib pajak juga telah diatur dalam Pasal 11 huruf i Peraturan Menteri Keuangan Republik Indonesia Nomor 184/PMK.03/2015. Dalam peraturan tersebut dijelaskan bahwa Fiskus memiliki kewajiban untuk melakukan pembinaan kepada Wajib Pajak dalam memenuhi kewajiban perpajakannya sesuai dengan ketentuan peraturan perundangundangan perpajakan dengan menyampaikan saran secara tertulis. Dengan dibuatnya peraturan tersebut maka secara tidak langsung pemerintah telah berupaya untuk meningkatkan kepatuhan wajib pajak untuk melaksanakan kewajibannya untuk membayar pajak dengan cara memberikan tugas kepada fiskus untuk melakukan pendampingan kepada wajib pajak.

Hasil penelitian (Perera \& Erawati, 2017) mengenai kualitas pelayanan menyatakan bahwa kualitas pelayanan berpengaruh positif terhadap kepatuhan wajib pajak dalam membayar pajak bumi dan bangunan. Semakin tinggi kualitas pelayanan fiskus terhadap wajib pajak maka semakin tinggi pula tingkat kepatuhan wajib pajak dalam membayar pajak bumi dan bangunan. Dari pemaparan diatas dapat disimpulkan bahwa kualitas pelayanan diperkirakan akan berpengaruh kepada kepatuhan wajib pajak dalam membayar pajak bumi dan bangunan.

$\mathrm{H}_{4}$ : Pelayanan fiskus yang berkualitas
berpengaruh positif $r$ terhadap
kepatuhan wajib pajak membayar
pajak bumi dan bangunan

\section{METODOLOGI PENELITIAN}

\section{Rancangan Penelitian}

Tujuan penelitian ini adalah uji hipotesis. Uji hipotesis merupakan bagian yang sangat penting di dalam penelitian. Bagian ini menentukan apakah penelitian yang dilakukan cukup ilmiah atau tidak. Untuk melakukan uji hipotesis, peneliti harus menentukan sampel, mengukur 
instrumen, desain, dan mengikuti prosedur yang akan menuntun dalam pencarian data yang diperlukan. Data yang dikumpulkan kemudian dianalisis melalui prosedur analitis yang benar sehingga peneliti dapat melihat validitas dari hipotesis. Analisis dari data yang dikumpulkan tidak menghasilkan hipotesis terbukti atau tidak terbukti, melainkan mendukung atau tidak mendukung hipotesis (Kuncoro, 2013:62).

Rancangan penelitian yang akan digunakan untuk menganalisis penelitian ini adalah tipe penelitian kuantitatif dengan format deskriptif, yang bertujuan untuk menjelaskan, meringkaskan berbagai kondisi, situasi atau berbagai variabel yang timbul di masyarakat yang menjadi objek penelitian itu berdasarkan apa yang terjadi.

\section{Populasi dan Sampel Penelitian}

Menurut (Sugiyono, 2015:15) "populasi adalah wilayah generalisasi yang terdiri atas: obyek/subyek yang mempunyai kualitas dan karakteristik tertentu yang ditetapkan oleh peneliti untuk dipelajari dan kemudian ditarik kesimpulannya". Adapun populasi dalam penelitian ini meliputi wajib Pajak Bumi dan Bangunan yang tinggal di Jakarta Timur Khususnya Kecamatan Pasar Rebo.

Teknik pengumpulan sampel yang digunakan dalam penelitian ini adalah menggunakan purposive sampling. Purposive sampling yaitu sampel yang ditentukan dari populasi berdasarkan kriteria. Oleh karena itu penentuan sampel antara lain : Responden dalam penelitian ini adalah wajib Pajak Bumi dan Bangunan yang berdomisili di Kecamatan Pasar Rebo Kota Jakarta Timur dan Responden yang digunakan sebagai sampel adalah wajib pajak yang memiliki objek Pajak Bumi dan Bangunan. Penelitian ini di lakukan selama 6 bulan dan rentan waktu pengisian kuesioner pada penelitian ini adalah selama 14 hari. Alasan memilih daerah Pasar Rebo dikarenakan di daerah Pasar Rebo banyak ditemukan bangunan ataupun tanah yang di pasangi tanda oleh petugas pajak bahwa belum memenuhi kewajiban untuk membayar pajak bumi dan bangunan.

\section{Variabel Penelitian}

Dalam penelitian ini terdiri dari dua jenis variabel yaitu variabel bebas (independent variable) dan variabel terikat (dependent variable). Adapun variabel bebas dalam penelitian ini yaitu tingkat pendapatan (X1), pengetahuan (X2), kesadaran wajib pajak (X3) dan pelayanan petugas pajak (X4). Sedangkan variabel terikatnya yaitu kepatuhan wajib pajak dalam membayar Pajak Bumi dan Bangunan(Y).

\section{Metode Pengumpulan Data}

Sumber data yang digunakan dalam penelitian ini adalah data Primer. Yaitu data yang dikumpulkan melalui kuesioner dengan cara memberi seperangkat pertanyaan tertulis kepada responden yang berkaitan dengan variabel-variabel yang akan diuji dalam penelitian dan tiap jawaban diberikan nilai (score). Operasional penyebaran kuesioner dilakukan dengan cara mengirimkan link google form yang nantinya akan diisi oleh wajib pajak bumi dan bangunan di Kecamatan Pasar Rebo Kota Jakarta Timur.

\section{Instrumen Penelitian}

Penelitian ini menggunakan kuesioner sebagai instrumen. Kuesioner yang digunakan dalam penelitian ini terdiri dari lima bagian. Masing-masing bagian tersebut yang berhubungan dengan tingkat pendapatan, pengetahuan, kesadaran wajib pajak, pelayanan petugas pajak dan kepatuhan wajib pajak yang akan diisi atau dijawab oleh responden yaitu wajib pajak di Kecamatan Pasar Rebo Kota Jakarta Timur. Jenis pernyataan adalah tertutup dimana responden hanya memilih pada pilihan jawaban yang tersedia. Penelitian ini menggunakan skala likert. Skala likert menurut Sugiyono (2010:93) adalah skala yang digunakan untuk mengukur 
sikap, pendapat dan persepsi seseorang atau sekelompok orang tentang fenomena sosial. Untuk setiap jawaban diberi skor 1 sampai 4. Angka 1 menunjukkan Sangat Tidak Setuju (STS), angka 2 menunjukkan Tidak Setuju (TS), angka 3 menunjukkan Setuju (S), dan angka 4 menunjukkan Sangat Setuju (SS).

\section{Analisis Data}

Metode analisis data yang digunakan dalam penelitian ini adalah metode analisis statistik menggunakan software statistika dan data versi 13 (STATA 13). Metode analisis data yang digunakan pada penelitian ini adalah structural equation modeling (SEM) yang bertujuan untuk mengungkapkan pengaruh antara beberapa variabel bebas dengan variabel terikat.

\section{Statistik Deskriptif}

Menurut (Sugiyono, 2015:147) statistik deskriptif adalah statistik yang digunakan untuk mendeskripsikan atau menggambarkan data yang telah dikumpul sebagaimana adanya tanpa bermaksud untuk menarik kesimpulan yang berlaku secara generalisasi. Dalam statistik deskriptif, hasil jawaban responden akan dideskripsikan menurut masing-masing variabel penelitian.

\section{Uji Kualitas Data}

Sebelum data dianalisis lebih lanjut maka akan dilakukan uji validitas dan reliabilitas lebih dulu. Kualitas data yang dihasilkan dari penggunaan instrumen penelitian dapat dievaluasi melalui uji validitas dan reliabilitas. Pengujian tersebut masing-masing untuk mengetahui konsistensi dan akurasi data yang dikumpulkan dari penggunaan instrument. Uji validitas yaitu untuk mengukur sah atau tidaknya suatu kuesioner, suatu kuesioner dikatakan valid jika pertanyaan pada kuesioner mengungkapkan sesuatu yang akan diukur oleh kuesioner tersebut. Nilai koefisien korelasi antara skor setiap item dengan skor total dihitung dengan analisis corrected item-total correlation. Apabila koefisien korelasi $r$ hitung lebih besar dibandingkan koefisien $r$ tabel pada taraf signifikansi $5 \%$ atau $10 \%$ suatu instrume dinyatakan valid (Ghozali, 2012:49). Uji reliabilitas adalah alat untuk mengukur suatu kuesioner yang merupakan indikator dari variabel atau konstruk. Butir pertanyaan dinyatakan reliabel atau handal jika jawaban seseorang terhadap pernyataan adalah konsisten (Sunyoto, 2011:67). Pengujian reliabilitas dengan menggunakan cronbach alpha ( $\alpha$ ). Koefisien cronbach alpha yang lebih dari 0,60 menunjukkan keandalan (reliabilitas) instrume. Selain itu, semakin mendekati 1 menunjukkan semakin tinggi konsistensi internal kesungguhan responden dalam menjawab semua item pernyataan penelitian (Ghozali, 2012:19).

\section{Analisis Model Struktural}

Menurut Stoelting, (Ricka, 2006), menyatakan bahwa SEM berkembang dan mempunyai fungsi mirip dengan regresi berganda. Sekalipun demikian nampaknya SEM menjadi suatu teknik analisis yang lebih kuat karena mempertimbangkan pemodelan interaksi, non linieritas, variabel-variabel bebas yang berkorelasi (correlated independents), kesalahan pengukuran, gangguan kesalahan-kesalahan yang berkorelasi (correlated error terms), di mana masing-masing diukur dengan menggunakan banyak indikator, dan satu atau dua variabel tergantung laten yang masing-masing juga diukur dengan beberapa indikator. Dengan demikian, menurut definisi ini SEM dapat digunakan sebagai alternatif lain yang lebih kuat dibandingkan dengan menggunakan regresi berganda, analisis jalur, analisis faktor, analisis time series, dan analisis kovarian (Umi Narimawati, Jonathan Sarwono: 2017).

\section{Uji Hipotesis}

Dalam penelitian ini analisis hipotesis digunakan dengan uji z. Uji z digunakan untuk menguji apakah masing-masing variabel bebas, secara individu berpengaruh terhadap variabel terikat. 
Pada uji z taraf signifikan yang digunakan adalah $5 \%$. Jika nilai $z$ hitung lebih besar dari $z$ tabel dan nilai $P>|z|$ lebih rendah dari taraf signifikansi maka menunjukkan bahwa variabel bebas berpengaruh secara signifikan terhadap variabel terikat. Namun jika nilai z hitung lebih kecil dari $z$ tabel dan nilai $P>|z|$ lebih besar dari taraf signifikansi maka menunjukkan bahwa variabel bebas tidak berpengaruh secara signifikan terhadap variabel terikat.

\section{HASIL DAN PEMBAHASAN}

\section{Responden Penelitian}

Responden penelitian ini adalah wajib pajak yang ada di Kecamatan Pasar Rebo yang memiliki kewajiban untuk membayar pajak bumi dan bangunan. Teknik pengambilan sampel menggunakan teknik Purposive Sampling yaitu dengan kriteria. Terdapat 110 sampel kuesioner yang diisi oleh responden. Sampel ini yang akan digunakan untuk analisis data dan pengujian hipotesis.

Penyebaran kuesioner dalam penelitian ini dilakukan melalui google form dikarenakan pada tahun 2020 terjadi pandemic Covid-19. Sehingga dalam hal penyebaran kuesioner tidak dapat disebarkan secara langsung. Pada pengambilan data untuk keperluan penelitian ini. Data yang diminta adalah jumlah pendapatan wajib pajak bumi dan bangunan di Kecamatan Pasar Rebo, pengetahuan wajib pajak tentang pajak bumi dan bangunan, kesadaran wajib pajak tentang pajak bumi dan bangunan, pelayanan petugas pajak dan kepatuhan wajib pajak membayar pajak bumi dan bangunan.

\section{Analisis Karakteristik Responden}

Analisis karakteristik pada responden ini diantaranya adalah jenis kelamin, usia, pendidikan terakhir, jenis pekerjaan dan pendapatan yang diterima selama sebulan.

Karakteristik responden berdasarkan jenis kelamin menunjukan hasil bahwa laki-laki memiliki jumlah 63 responden (57\%) dan perempuan memiliki jumlah 47 responden (43\%). Dalam hal ini responden laki-laki lebih mendominasi. Berdasarkan usia diatas 45 tahun dengan jumlah 48 responden (44\%). Untuk usia kurang dari 25 tahun memiliki jumlah 15 responden (14\%), untuk usia 23-35 tahun memiliki jumlah 23 responden (21\%) dan untuk usia 36-45 tahun memiliki jumlah 24 responden (22\%). Bersadarkan tingkat pendidikan SMA yakni sebesar (53\%), tingkat pendidikan Sarjana yakni sebesar (34\%). SD,SMP dan D1-D3 berturut-turut memiliki prosentase $(3 \%),(2 \%)$ dan $(6 \%)$. Sedangkan untuk Magister dan lainnya memiliki prosentase (1\%). Berdasarkan jenis pekerjaan Karyawan Swasta dengan (73\%), Pegawai Negeri Sipil dengan $(12 \%)$, Wirausaha dengan (8\%), Guru dengan $(5 \%)$ dan Dosen dengan (2\%). Berdasarkan pendapatan yang diterima selama sebulan (73\%) responden memiliki pendapatan lebih besar atau sama dengan UMR Jakarta, untuk (27\%) responden menyatakan bahwa pendapatannya berada dibawah UMR Jakarta.

\section{Uji Validitas}

Perhitungan pada penelitian ini menggunakan program STATA versi 13. Syarat pengujian tersebut dikatakan valid apabila hasil uji validitas tersebut nilai koefisien korelasi ( $r$ tabel) lebih dari 0,1874 ( $r$ hitung $>r$ tabel).

\section{Tabel 1}

Hasil Uji Validitas

\begin{tabular}{|l|l|l|l|}
\hline Variabel & Indikator & $\begin{array}{c}\text { Koefisi } \\
\text { en } \\
\text { Korela } \\
\text { si }\end{array}$ & $\begin{array}{c}\text { Keterang } \\
\text { an }\end{array}$ \\
\hline $\begin{array}{l}\text { Tingkat } \\
\text { Pendapat } \\
\text { an (X1) }\end{array}$ & \begin{tabular}{l} 
Sumber \\
Pendapata \\
\cline { 2 - 4 }
\end{tabular} & 0,4244 & Valid \\
\cline { 2 - 4 } & $\begin{array}{l}\text { Pendapata } \\
\text { n yang } \\
\text { diperoleh } \\
\text { untuk } \\
\text { memenuhi } \\
\text { kebutuhan }\end{array}$ & 0,4150 & Valid \\
\hline $\begin{array}{l}\text { Pengetahu } \\
\text { an dasar }\end{array}$ & 0,4140 & Valid \\
\hline
\end{tabular}




\begin{tabular}{|c|c|c|c|}
\hline \multirow[b]{2}{*}{\begin{tabular}{|l} 
Tingkat \\
Pengetah \\
uan (X2)
\end{tabular}} & $\begin{array}{l}\text { tentang } \\
\text { PBB }\end{array}$ & & \\
\hline & $\begin{array}{l}\text { Pengetahu } \\
\text { an tentang } \\
\text { tata cara } \\
\text { pembayara } \\
\text { n dan } \\
\text { sanksi } \\
\text { keterlamba } \\
\text { tan }\end{array}$ & 0,5186 & Valid \\
\hline \multirow[t]{2}{*}{$\begin{array}{l}\text { Tingkat } \\
\text { Kesadara } \\
\text { n (X3) }\end{array}$} & $\begin{array}{l}\text { Kesadaran } \\
\text { wajib pajak } \\
\text { PBB }\end{array}$ & 0,6402 & Valid \\
\hline & \begin{tabular}{|l|} 
Kesadaran \\
Sanksi dan \\
pelaporan \\
perubahan
\end{tabular} & 0,6133 & Valid \\
\hline $\begin{array}{l}\text { Pelayanan } \\
\text { Petugas }\end{array}$ & $\begin{array}{l}\text { Sosialisasi } \\
\text { Informasi }\end{array}$ & 0,6675 & Valid \\
\hline Pajak (X4) & $\begin{array}{l}\text { Kemudaha } \\
\text { n } \\
\text { Pembayar } \\
\text { an dan } \\
\text { Pelayanan }\end{array}$ & 0,6067 & Valid \\
\hline $\begin{array}{l}\text { Kepatuha } \\
\text { n } \\
\text { Membayar } \\
\text { Pajak } \\
\text { Bumi dan } \\
\text { Bangunan }\end{array}$ & $\begin{array}{l}\text { Kepatuhan } \\
\text { wajib pajak } \\
\text { dalam } \\
\text { memenuhi } \\
\text { kewajiban } \\
\text { PBB } \\
\end{array}$ & 0,5562 & Valid \\
\hline (Y) & \begin{tabular}{|l|} 
Wajib \\
Pajak \\
bersedia \\
memberika \\
n informasi \\
PBB
\end{tabular} & 0,5964 & Valid \\
\hline
\end{tabular}

Berdasarkan hasil uji validitas pada variabel Tingkat Pendapatan (X1), Tingkat Pengetahuan (X2), Tingkat Kesadaran (X3) dan Pelayanan Petugas Pajak (X4) terhadap Kepatuhan Membayar Pajak Bumi dan Bangunan (Y) menunjukkan bahwa masing-masing indikator dari variabel yang diuji hasil koefisien korelasinya lebih besar dari 0,1874 maka dinyatakan valid.

\section{Uji Reliabilitas}

Perhitungan pada penelitian ini menggunakan program STATA versi 13. Syarat pengujian tersebut dikatakan reliabel apabila hasil uji reliabilitas tersebut Alpha Cornbach's lebih dari 0,60.
Tabel 2

Hasil Uji Reliabilitas

\begin{tabular}{|l|c|c|}
\hline \multicolumn{1}{|c|}{ Variabel } & $\begin{array}{c}\text { Alpha } \\
\text { Cornbach's }\end{array}$ & Keterangan \\
\hline $\begin{array}{l}\text { Tingkat } \\
\text { Pendapatan } \\
\text { (X1) }\end{array}$ & 0,7359 & Reliabel \\
\hline $\begin{array}{l}\text { Tingkat } \\
\text { Pengetahuan } \\
\text { (X2) }\end{array}$ & 0,7265 & Reliabel \\
\hline $\begin{array}{l}\text { Tingkat } \\
\text { Kesadaran } \\
\text { (X3) }\end{array}$ & 0,6780 & Reliabel \\
$\begin{array}{l}\text { Pelayanan } \\
\text { Petugas } \\
\text { Pajak (X4) }\end{array}$ & 0,7661 & Reliabel \\
\hline $\begin{array}{l}\text { Kepatuhan } \\
\text { Membayar } \\
\text { Pajak Bumi } \\
\text { dan } \\
\text { Bangunan } \\
\text { (Y) }\end{array}$ & 0,7082 & Reliabel \\
\hline
\end{tabular}

Berdasarkan hasil uji reliabilitas diatas, diperoleh variabel Tingkat Pendapatan (X1) memiliki nilai Alpha Cornbach's sebesar 0,7359 , variabel Tingkat Pengetahuan (X2) memiliki nilai Alpha Cornbach's sebesar 0,7265, variabel Tingkat Kesadaran (X3) memiliki nilai Alpha Cornbach's sebesar 0,6780, variabel Pelayanan Petugas Pajak (X4) memiliki nilai Alpha Cornbach's sebesar 0,7661, dan variabel Kepatuhan Membayar Pajak Bumi dan Bangunan (Y) memiliki nilai Alpha Cornbach's sebesar 0,7082 . Jadi, dapat disimpulkan bahwa semua variabel $X$ dan variabel $Y$ dalam penelitian ini dapat dipercaya atau reliabel, dikarenakan Alpha Cornbach's melebihi 0,6.

\section{Analisis Model Struktural}

\section{Tabel 3}

Hasil Uji Model Struktural

\begin{tabular}{|c|c|c|c|c|}
\hline Variabel & $\begin{array}{c}\text { Hipotesis } \\
\text { Awal }\end{array}$ & Coef & $\mathbf{z}$ & $\mathbf{P}>|\mathbf{z}|$ \\
\hline PDT (X1) & $\begin{array}{c}\text { Positif } \\
\left(\mathrm{H}_{1}\right)\end{array}$ & 0,2179 & 4,08 & $0,021^{*}$ \\
\hline PNT (X2) & $\begin{array}{c}\text { Positif } \\
\left(\mathrm{H}_{2}\right)\end{array}$ & $-0,1603$ & $-4,22$ & $0,018^{*}$ \\
\hline $\begin{array}{c}\text { KSD } \\
(\mathrm{X} 3)\end{array}$ & $\begin{array}{c}\text { Positif } \\
\left(\mathrm{H}_{3}\right)\end{array}$ & 0,4482 & 5,52 & $0,003^{*}$ \\
\hline
\end{tabular}




\begin{tabular}{|c|c|c|c|c|}
\hline PP (X4) & $\begin{array}{c}\text { Positif } \\
\left(\mathrm{H}_{4}\right)\end{array}$ & 0,4856 & 6,18 & $0,001 *$ \\
\hline \multicolumn{5}{|c|}{$\begin{array}{l}*=\text { Taraf signifikan } 0,05 \\
* *=\text { Taraf signifikan } 0,01 \\
\text { PDT = Tingkat Pendapatan Wajib Pajak } \\
\text { PNT = Tingkat Pengetahuan Wajib Pajak } \\
\text { KSD = Tingkat Kesadaran Wajib Pajak } \\
\text { PPP = Pelayanan Petugas Pajak }\end{array}$} \\
\hline
\end{tabular}

\section{Hasil Pengujian Hipotesis}

Pengujian hipotesis dilakukan dengan structural equation modeling (SEM). Pengujian ini digunakan untuk mengetahui seberapa besar pengaruh variabel bebas yaitu Tingkat Pendapatan (X1), Pengetahuan (X2), Kesadaran Wajib Pajak (X3) dan Pelayanan Petugas Pajak (X4) terhadap variabel terikat yaitu Kepatuhan Wajib Pajak Membayar Pajak Bumi dan Bangunan (Y). Dari hasil pengujian yang disajikan pada tabel 3 , menunjukan hasil uji hipotesis $\left(\mathrm{H}_{1}\right)$ bahwa variabel tingkat pendapatan terhadap kepatuhan membayar pajak bumi dan bangunan menunjukan nilai $\mathrm{z}$ sebesar 4,08 lebih besar dari nilai $z$ tabel sebesar 1,96 dan memiliki nilai probabilitas sebesar 0,021 lebih rendah dari taraf signifikan yaitu 0,05 . Sehingga dapat disimpulkan bahwa variabel tingkat pendapatan berpengaruh secara signifikan terhadap variabel kepatuhan membayar pajak bumi dan bangunan. Pada uji hipotesis $\left(\mathrm{H}_{1}\right)$ yang telah dikemukakan di atas diperoleh nilai coefficient sebesar 0,2179. Pengujian ini membuktikan bahwa tingkat pendapatan berpengaruh positif $(0,2179)$ dan signifikan $\quad(0,021<0,05) \quad$ terhadap kepatuhan wajib pajak dalam membayar pajak bumi dan bangunan, sehingga hipotesis $\left(\mathrm{H}_{1}\right)$ dalam penelitian ini diterima. Hal tersebut sejalan dengan hasil penelitian yang dilakukan oleh Dewi, dkk. (2017) yang menunjukkan bahwa semakin tinggi pendapatan wajib pajak maka kepatuhan wajib pajak semakin tinggi pula, dan sebaliknya semakin rendah pendapatan wajib pajak maka semakin rendah pula kepatuhan wajib pajak.
Hasil uji hipotesis $\left(\mathrm{H}_{2}\right)$ menunjukan bahwa variabel tingkat pengetahuan terhadap kepatuhan membayar pajak bumi dan bangunan menunjukan nilai $z$ sebesar -4,22 lebih kecil dari nilai z tabel sebesar 1,96 dan memiliki nilai probabilitas sebesar 0,018 lebih rendah dari taraf signifikan yaitu 0,05 . Sehingga dapat disimpulkan bahwa variabel tingkat pengetahuan tidak berpengaruh terhadap variabel kepatuhan membayar pajak bumi dan bangunan. Pada uji hipotesis $\left(\mathrm{H}_{2}\right)$ yang telah dikemukakan di atas diperoleh nilai coefficient sebesar $-0,1603$. Pengujian ini membuktikan bahwa tingkat pengetahuan berpengaruh negatif ($0,1603)$ dan signifikan $(0,018<0,05)$ terhadap kepatuhan membayar pajak bumi dan bangunan sehingga hipotesis $\left(\mathrm{H}_{2}\right)$ dalam penelitian ini ditolak. Hal tersebut sejalan dengan hasil penelitian yang dilakukan oleh (Fitrianingsih, dkk. 2018) yang menunjukkan bahwa pengetahuan tidak menjamin bahwa wajib pajak akan lebih patuh dalam melaksanakan kewajibannya.

Hasil uji hipotesis $\left(\mathrm{H}_{3}\right)$ menunjukan bahwa variabel tingkat kesadaran terhadap kepatuhan membayar pajak bumi dan bangunan menunjukan nilai $z$ sebesar 5,34 lebih besar dari nilai z tabel sebesar 1,96 dan memiliki nilai probabilitas sebesar 0,003 lebih rendah dari taraf signifikan yaitu 0,05 . Sehingga dapat disimpulkan bahwa variabel tingkat kesadaran berpengaruh secara signifikan terhadap variabel kepatuhan membayar pajak bumi dan bangunan. Pada uji hipotesis $\left(\mathrm{H}_{3}\right)$ yang telah dikemukakan di atas diperoleh nilai coefficient sebesar 0,4482 . Pengujian ini membuktikan bahwa tingkat kesadaran berpengaruh positif $(0,4482)$ dan signifikan $(0,003<0,05) \quad$ terhadap kepatuhan membayar pajak bumi dan bangunan sehingga hipotesis $\left(\mathrm{H}_{3}\right)$ dalam penelitian ini diterima. Hal tersebut sejalan dengan hasil penelitian yang dilakukan oleh (Parera \& Erawati, 2017) dan Salma, 2018) yang menunjukkan bahwa semakin tinggi tingkat kesadaran wajib pajak bumi dan bangunan maka semakin tinggi pula 
tingkat kepatuhan wajib pajak dalam membayar pajak bumi dan bangunan.

Hasil uji hipotesis $\left(\mathrm{H}_{4}\right)$ menunjukan bahwa variabel pelayanan petugas pajak terhadap kepatuhan membayar pajak bumi dan bangunan menunjukan nilai $z$ sebesar 6,18 lebih besar dari nilai z tabel sebesar 1,96 dan memiliki nilai probabilitas sebesar 0,001 lebih rendah dari taraf signifikan yaitu 0,05 . Sehingga dapat disimpulkan bahwa variabel pelayanan petugas pajak berpengaruh secara signifikan terhadap variabel kepatuhan membayar pajak bumi dan bangunan. Pada uji hipotesis $\left(\mathrm{H}_{4}\right)$ yang telah dikemukakan di atas diperoleh nilai coefficient sebesar 0,4856 . Pengujian ini membuktikan bahwa pelayanan petugas pajak berpengaruh positif $(0,4856)$ dan signifikan $\quad(0,001<0,05) \quad$ terhadap kepatuhan membayar pajak bumi dan bangunan sehingga hipotesis $\left(\mathrm{H}_{4}\right)$ dalam penelitian ini diterima. Hal ini sejalan dengan hasil penelitian yang dilakukan oleh (Puspita, 2014) dan (Parera \& Erawati, 2017) yang menunjukkan bahwa semakin baik kualitas pelayanan fiskus yang diberikan maka kepatuhan wajib pajak akan meningkat.

Berdasarkan hasil analisis data dan pembahasan yang telah diuraikan sebelumnya, maka dapat ditarik kesimpulan yaitu (1) Tingkat Pendapatan berpengaruh positif dan signifikan terhadap Kepatuhan Membayar Pajak Bumi dan Bangunan Hal tersebut sejalan dengan hasil penelitian yang dilakukan oleh (Dewi, dkk. 2017), (2) Tingkat Pengetahuan tidak berpengaruh terhadap Kepatuhan Membayar pajak Bumi dan Bangunan Hal tersebut sejalan dengan penelitian yang dilakukan oleh (Fitrianingsih, dkk. 2018), (3) Tingkat Kesadaran berpengaruh positif dan signifikan terhadap Kepatuhan Membayar Pajak Bumi dan Bangunan Hal tersebut sejalan dengan penelitian yang dilakukan oleh (Parera \& Erawati, 2017) dan (Salma, 2018), (4) Pelayanan Petugas Pajak berpengaruh positif dan signifikan terhadap Kepatuhan Membayar Pajak Bumi dan Bangunan Hal tersebut sejalan dengan penelitian yang dilakukan oleh (Puspita, 2014) dan (Perera \& Erawati, 2017).

\section{IMPLIKASI DAN KETERBATASAN}

Mengacu pada hasil penelitian dan pembahasan dalam penelitian ini, maka diharapkan dapat memberi implikasi sebagai berikut: (1) Wajib Pajak diharapkan dapat meningkatkan kesadaran dalam memenuhi kewajibannya yaitu membayar pajak khususnya Pajak Bumi dan Bangunan. (2) Petugas pajak diharapkan dapat meningkatkan pelayanannya seperti memberikan sosialisasi kepada wajib pajak sehingga dapat meningkatkan kesadaran wajib pajak dan mendorong kepatuhan wajib pajak dalam membayarkan Pajak Bumi dan Bangunan.

Selama pelaksanaan penelitian ini terdapat beberapa keterbatasan. Beberapa keterbatasan tersebut diantaranya adalah sebagai berikut: (1) Kontrol terhadap kemampuan sampel penelitian ini hanya meliputi variabel tingkat pendapatan, pengetahuan, kesadaran dan pelayanan petugas pajak. Variabel lainnya seperti sanksi perpajakan, sikap wajib pajak dan tingkat pendidikan wajib pajak. Hal tersebut tidak menutup kemungkinan bahwa hasil penelitian dapat dipengaruhi oleh variabel lain di luar variabel yang telah ditentukan dalam penelitian ini. (2) Sampel penelitian yang diambil oleh peneliti hanya terbatas pada Kecamatan Pasar Rebo Kota Jakarta Timur. (3) Pengumpulan dan pengisian kuesioner oleh responden memakan waktu yang cukup lama dikarenakan pada tahun 2020 sedang terjadi wabah virus Covid-19 sehingga peneliti tidak dapat langsung memberikan kuesioner kepada responden namun sebagai gantinya peneliti menggunakan google form.

Peneliti menyadari bahwa penelitian ini masih jauh dari kata sempurna, untuk itu berikut adalah saran 
bagi peneliti selanjutnya yang dapat menjadi bahan pertimbangan untuk melakukan penelitian dengan topik yang sama: (1) Sampel yang sedikit menjadi salah satu kendala dari penelitian ini, diharapkan penelitian selanjutnya dapat menambah jumlah sampel dengan menambahkan rentang waktu penelitian. (2) Penelitian selanjutnya diharapkan dapat menambah variabel bebas, karena pada penelitian ini hanya menggunakan 4 variabel yaitu tingkat pendapatan, pengetahuan, kesadaran dan pelayanan petugas pajak. (3) Melalui penelitian ini, diharapkan akan ada penelitian-penelitian lain seputar kepatuhan wajib pajak bumi dan bangunan yang baru.

\section{REFERENCES}

Agustiantono, Dwi. 2012. Analisis FaktorFaktor yang Mempengaruhi Kepatuhan Wajib Pajak Orang Pribadi: Aplikasi TPB (Studi Empiris WPOP Di Kabupaten Pati).Semarang: Program Sarjana Fakultas Ekonomika dan Bisnis Universitas Diponegoro.

Ariani, M., \& Biettant, R. 2019. Pengaruh Pelayanan Fiskus Terhadap Kepatuhan Wajib Pajak Dengan Variabel Intervening Kepuasan Wajib Pajak. Jurnal Informasi, Perpajakan, Akuntansi, dan Keuangan Publik, 13(1), 15-30.

Budhiartama, I. G. P., \& Jati, I. K. (2016). Pengaruh sikap, kesadaran wajib pajak dan pengetahuan perpajakan pada kepatuhan membayar pajak bumi dan bangunan. E-Jurnal Akuntansi, 15(2), 1510-1535.

Burton, llyas. 2011. Hukum Pajak. Edisi 5. Jakarta: Penerbit Salemba Empat. Diana, Anastasia dan Setiawati Lilis. 2014. Perpajakan Teori dan Peraturan Terkini. Yogyakarta: Penerbit ANDI.

Dewi, Diatmika, Yasa. 2017. Pengaruh Penerimaan Surat Pemberitahuan Pajak Terutang (SPPT), Pendapatan Wajib Pajak, Dan Kesadaran Wajib Pajak Terhadap Kepatuhan Wajib Pajak Bumi dan Bangunan Perdesaan Dan
Perkotaan (PBB-P2) DI Kabupaten Buleleng. Jurnal Akuntansi. Vol.8. No.2 Tahun 2017.

Ernawati. 2014. Pengaruh Tingkat Pendidikan, Pendapatan, dan Kualitas Pelayanan Fiskus terhadap Kepatuhan Wajib Pajak. Skripsi. Fakultas Ekonomi dan Bisnis Universitas Hasanuddin.

Faizah, Siti. 2009. Faktor-Faktor yang Mempengaruhi Kepatuhan Wajib Pajak dalam Membayar Pajak Bumi dan Bangunan (Studi Kasus di Kecamatan Dukuhturi Kabupaten Tegal. Skripsi. Fakultas Ekonomi Universitas Negeri Semarang.

Fitrianingsih, Sudarno, Kurrohman. 2018. Analisis Pengaruh Pengetahuan Perpajakan, Pelayanan Fiskus dan Denda Terhadap Kepatuhan Wajib Pajak Dalam Membayar Pajak Bumi dan Bangunan Perdesaan Dan Perkotaan Di Kota Pasuruan. Pasuruan. E-Jurnal Ekonomi dan Akuntansi.Vol.V. No.1.

Gusar, Helen Stephanie. 2015. Pengaruh Sosialisasi Pemerintah, Pengetahuan Perpajakan, Sanksi Pajak, Kesadaran Pajak, dan Kualitas Pelayanan Terhadap Kepatuhan Wajib Pajak Dalam Membayar Pajak Bumi dan Bangunan. Jurnal Akuntansi. Vol.2. No.2 Oktober 2015.

Haswidar. 2016. Pengaruh Tingkat Pendapatan, Pengetahuan, dan Kesadaran Wajib Pajak Terhadap Kepatuhan Membayar Pajak Bumi dan Bangunan di Kecamatan Pammana Kabupaten Wajo. Skripsi. Fakultas Ekonomi dan Bisnis Universitas Hassanudin.

Ibtida, R. 2010. Pengaruh kesadaran wajib pajak dan pelayanan fiskus terhadap kinerja penerimaan pajak dengan kepatuhan wajib pajak sebagai variabel intervening (studi pada wajib pajak di Jakarta Selatan).

Koentarto, Ilham. 2011. Analisis FaktorFaktor yang Mempengaruhi Kepatuhan Masyarakat dalam Melakukan Pembayaran Pajak Bumi dan Bangunan (Studi Kasus 
pada Kecamatan Arut Selatan Kabupaten Kota Waringin Barat). Jurnal. Vol.V. No.2.

Mardiasmo. 2013. Perpajakan Edisi Revisi. Yogyakarta: Penerbit ANDI.

Nafiah, Z., \& Warno, W. 2018. Pengaruh Sanksi Pajak, Kesadaran Wajib Pajak, Dan Kualitas Pelayanan Pajak Terhadap Kepatuhan Wajib Pajak Dalam Membayar Pajak Bumi Dan Bangunan (Study Kasus Pada Kecamatan Candisari Kota Semarang Tahun 2016). JURNAL STIE SEMARANG (EDISI ELEKTRONIK), 10(1), 86-105.

Oktafiyanto, I., \& Wardani, D. K. 2015. Pengaruh pemahaman wajib pajak, kesadaran wajib pajak, dan pelayanan fiskus terhadap kepatuhan wajib pajak bumi dan bangunan. Jurnal Akuntansi, 3(1), 41-52.

Peraturan Daerah DKI Jakarta Nomor 16 tahun 2011. Tentang Pajak Bumi dan Bangunan Perdesaan dan Perkotaan.

Parera, A. M. W., \& Erawati, T. (2017). Pengaruh Kesadaran Wajib Pajak, Sanksi Perpajakan, Pengetahuan Perpajakan, dan Pelayanan Fiskus Terhadap Kepatuhan Wajib Pajak Bumi dan Bangunan. Jurnal Akuntansi. Vol.5. No.1 Juni 2017.

Purbo, Jati. 2012. Analisis Faktor-Faktor Yang Mempengaruhi Kepatuhan Wajib Pajak Badan Pada Perusahaan Industri Manufaktur Di Semarang. Skripsi. Semarang: Program Sarjana Fakultas Ekonomi Universitas Diponegoro.

Puspita, N. 2014. Pengaruh kualitas pelayanan fiskus, kesadaran wajib pajak dan keadilan pajak terhadap kepatuhan wajib pajak dalam membayar pajak bumi dan bangunan. Jurnal Akuntansi, 2(1).

Rahman, A. 2018. Pengaruh Kesadaran Wajib Pajak, Tingkat Pendidikan, Dan Pendapatan Terhadap Kepatuhan Membayar Pajak Bumi Dan Bangunan. Jurnal Akuntansi, 6(1).

Rantumbanua, C. A., Kasenda, V., \& Undap, G. 2017. Kesadaran
Masyarakat Dalam Membayar Pajak Bumi dan Bangunan di Desa Pinabetengan Utara Kecamatan Tomposo Barat Kabupaten Minahasa. Jurnal Eksekutif, 2(2).

Salmah, Siti. 2018. Pengaruh Pengetahuan dan Kesadaran Wajib Pajak Terhadap Kepatuhan Wajib Pajak Dalam Membayar Pajak Bumi dan Bangunan (PBB). Jurnal Akuntansi. Vol.1. No.2 April 2018.

Sapriadi, D. (2013). Pengaruh kualitas pelayanan pajak, sanksi pajak dan kesadaran wajib pajak terhadap kepatuhan wajib pajak dalam membayar PBB (Pada Kecamatan Selupu Rejang). Jurnal Akuntansi, 1(1).

Saputra, Robert. 2015. Pengaruh Sanksi, Kesadaran Perpajakan, dan Kualitas Pelayanan Wajib Pajak terhadap Kepatuhan Wajib Pajak Bumi dan Bangunan (Studi Empiris pada Wajib Pajak Kabupaten Pasaman). Skripsi. Padang: Fakultas Ekonomi dan Bisnis.

Sugiyono. 2015. Metode Penelitian Bisnis (Pendekatan Kuantitatif, Kualitatif dan R\&D). Bandung: Penerbit Alfabet.

Sukur. 2015. Efektivitas dan Kontribusi Pajak Bumi Bangunan Perdesaan dan Perkotaan (PBB-P2) terhadap PAD di Kapubaten Konawe. Skripsi. Makassar. Fakultas Ekonomi dan Bisnis Universitas Hasanuddin.

Undang-Undang Nomor 32 Tahun 2004. Tentang Pemerintahan Daerah. 2004. Jakarta: Direktorat Jenderal Otonomi Daerah.

Undang-Undang Nomor 33 Tahun 2004. Tentang Perimbangan Keuangan antara Pemerintah Pusat dan Daerah. 2004. Jakarta: Sekretaris Negara Republik Indonesia.

Undang-Undang Nomor 28 Tahun 2009. Tentang Pajak Daerah dan Retribusi Daerah. 2009. Jakarta: Sekretaris Negara Republik Indonesia.

Undang-Undang Nomor 12 Tahun 1994. Tentang Perubahan Atas UndangUndang Nomor 12 Tahun 1985 tentang Pajak Bumi dan Bangunan. 
1994. Jakarta: Menteri Negara Sekretaris Negara Republik Indonesia.

Utomo, B.A, Wahyu. 2011. Pengaruh Sikap, Kesadaran Wajib Pajak, dan Pengetahuan Perpajakan terhadap Kepatuhan Wajib Pajak dalam Membayar Pajak Bumi dan Bangunan di Kecamatan Pamulang Kota Tangerang Selatan. Skripsi. Fakultas Ekonomi dan Bisnis Universitas Islam Negeri Syarif Hidayatullah.

Widowati, R. 2014. Kepatuhan wajib pajak melalui sosialisasi perpajakan, sanksi perpajakan, pengetahuan pajak dan pelayanan fiskus. Skripsi. Semarang.

Wulandari, T., \& Suyanto, S. (2014). Pengaruh Pengetahuan Perpajakan, Tingkat Pendidikan, Dan Sanksi Administrasi Terhadap Kepatuhan Wajib Pajak Dalam Melakukan Pembayaran Pajak Bumi Dan Bangunan (Studi Kasus Pada Kantor Dinas Pendapatan Daerah Kabupaten Sleman). Jurnal Akuntansi, 2(2), 94-102.

Yusnidar, Sunarti, Prasetya. 2014. Pengaruh Faktor-Faktor yang Mempengaruhi Kepatuhan Wajib Pajak dalam Melakukan Pembayaran Pajak Bumi dan Bangunan Perdesaan dan Perkotaan (Studi pada Wajib Pajak PBB-P2 Kecamatan Jombang Kabupaten Jombang). Jurnal Akuntansi. Vol.V. No.2. 